\title{
The Influence of Social Guidance Services to Consumptive Behavior of Junior High Students
}

\author{
Hans Pontororing \\ Department of Guidance and Counseling \\ Universitas Negeri Manado, Manado \\ pontororinghansfip2019@gmail.com
}

\begin{abstract}
Consumptive behavior is behavior that is no longer based on rational considerations, but rather because of desires that have reached irrational levels again. Consumptive behavior is the human tendency to consume unlimited. Based on the observations of researchers at Brother Don Bosco Tomohon Junior High School, there were some students who had consumptive behavior. Therefore, researchers suspect students need to be equipped with social guidance services. This research uses quantitative methods. Subjects in this study determined $17 \%$ with the number of respondents as many as 34 students. Data analysis techniques in this study used simple regression analysis using SPSS version 23 computer program tools. From the research results obtained a regression equation $\hat{y}=104,608-0.324 X$. Significant test obtained t count of -2.250 and P-value of $0.031>0.05$. The results of this study support the Ha hypothesis proposed so that it can be accepted. The results of this study can be concluded that social guidance services have a positive influence on consumer behavior. This means that if there is an increase in social guidance services, there will be a decrease in consumer behavior. The power of determination is shown by $\mathrm{R}$ square 0.13 which means that $13.7 \%$ of the variance of consumptive behavior $(\mathrm{Y})$ is determined by the social guidance service variable.
\end{abstract}

Keywords: social guidance services, consumptive behavior

\section{INTRODUCTION}

Increasing times have shown high progress in various aspects of life. In addition to showing progress it also brings up a new lifestyle that can be called a modern lifestyle. This of course has an impact on human life, both positive and negative impacts. Such conditions can change people's habits and lifestyles towards lives that tend to be extravagant and excessive. Consumptive behavior is familiar to us. Consumptive behavior seems to be the current trend, especially in Indonesian society.

According to Sumartono (2002) consumer behavior is behavior that is no longer based on rational considerations, but because there is a desire that has reached an irrational level again, for example buying a product to maintain self-appearance, the emergence of the assessment that buying high-priced products will cause high confidence. Consumers usually buy goods because the goods are branded, it's all caused by consumers wanting to raise the status in the environment around them. Consumptive behavior is caused by internal factors such as psychological factors (motivation, perception, attitudes and beliefs), personal factors (age, occupation, economic situation, personality, gender) and external factors such as culture, social class, family.

Based on the observation of researchers while at the research site that many students who have consumptive behavior such as buying things that are not needed (just following their desires), already have a sophisticated cellphone and are still worthy of clothes but when there is the latest cellphone output they immediately buy the cellphone, so make parents complain because children's desires are too high and not in accordance with the parents' low economy and there are also complaints from teachers that many students do not buy textbooks but students buy more items according to their desires alone not on their needs. Therefore, students need to be equipped with social guidance services.

\section{METHOD}

The approach used in this study is a quantitative approach. The correlational method to see the effect of the independent variable on the dependent variable. Social service guidance is used as an independent variable (variable $\mathrm{X}$ ) and consumptive behavior as the dependent variable (Y). According to Arikunto (2013), the population is part of the whole of the subject or object of research. So that the population in this study are all Frateer Don Bosco Middle School students, totaling 200 people.

According to Sugiyono (2003) states that the sample is part of the number and characteristics possessed by the population. So, the sampling in this study refers to the opinion of Tuckman (19-99) stating that if the number of members of the population is large, sampling can be taken between $10 \%$ to $15 \%, 20$ to $25 \%$ or more. Based on this opinion, the number of sample members in this study was determined at $17 \%$ of the population members, so the number of sample members in this study was 34 . To obtain data from these two research variables, the questionnaire was used as the main instrument, in addition to observation and documentation. This research was conducted at Brother Don Bosco Tomohon Middle School. This research was carried out for 3 months.

\section{RESULT}

This research was conducted with a normality test using the P-P plot with the help of computer services SPSS program. Based on the SPSS output below, we can see a P-P plot graph. Where the P-P plot shows the point follows and approaches the diagonal line so that it can be concluded that the regression model meets the normality assumption.

The basis for decision making in the linearity test can be seen from the significant value $0.814>0.05$ which means that there is a significantly linear relationship 
between the social guidance variable $(\mathrm{X})$ and the consumer behavior (Y). Regression test is used to determine whether the data on the independent and dependent variables are linearly regressed.

This test was carried out with the help of SPSS 23 Software with a test for linearity at a significant level of $5 \%$. Variables can be said to linearly regression if the significance value of linearity is $>3.39$. After being tested using simple regression analysis the regression equation $=$ 104, $608-0.324 \mathrm{X}$ was obtained.

These results mean that there is a decrease in the social guidance service variable, there will be an increase in the consumer behavior variable. the comparison of the two variables quantitatively is $1:-0.324$ both of these variables indicate that there is an increase of once / unit in the social guidance variable, there will be a decrease of 0.324 / unit in the consumer behavior variable.

\section{DISCUSSION}

In connection with the results of testing the hypothesis above, it can be discussed as follows: in the study subjects were taken as many as 34 students taken from class IX, carried out random sampling at Brother Bos Bosom Tomohon Junior High School totaling 200 students. In this study social guidance as an effort to develop the ability of students to deal with and overcome the problem of consumptive behavior by creating a good educational interaction environment, developing a system of self-understanding of positive attitudes and developing personal abilities social.

According Arikunto (2011) argues that social guidance is a service provided by a supervisor to students with the aim of helping students to understand themselves in relation to the surrounding social environment. Meanwhile Sukardi (2005) argues that in social guidance, basically it is done to help students get to know and relate to their social environment which is based on noble character, social responsibility, and statehood.

Setiaji (1995) states that consumptive behavior is the tendency of someone to behave excessively in buying something or buying it unplanned. As a result, they then spend their money blindly and irrationally, just to get goods that they think can be a symbol of privilege. In connection with the results of this study it was found that there is an influence between social guidance services on consumptive behavior of students, meaning that the lower the social guidance service, the more consumptive behavior of students will increase.

This can be proven by a simple regression test obtained by the regression equation $\hat{y}=104,608$ $0.324 \mathrm{X}$. This means that if there is a decrease of 1 unit in the social guidance service variable, by itself the variable consumer behavior in students increases by 0.324 . The results of this study support the Ha hypothesis proposed so that it can be accepted. The results of the study revealed that social guidance services had a significant negative effect on consumptive behavior.

\section{CONCLUSION}

Based on the results of the data analysis and discussion of the research results stated in the previous chapter, it can be concluded that there is a negative influence between social guidance services on consumptive behavior.

For students, in Junior High School Brother Don Bosco Tomohon is expected to have a good understanding of consumptive behavior that can be detrimental, so students can reduce the behavior for themselves. For BK teachers it is very important that BK teachers have the knowledge and skills of counseling guidance in helping and dealing with students' problems. In order to be able to actualize himself for the present even a successful future.

\section{REFERENCES}

[1] Mugiarso, Heru. 2005. Bimbingan dan Konseling. Semarang: UPT MKK Universitas Negeri Semarang.

[2] K Kadir. 2016. Statistika Terapan Konsep, Contoh dan Analisis Data dengan Program SPSS/Lisrel dalam penelitian. Jakarta: Rajawali Pers.

[3] Sugiyono. 2003. Metode Penelitian. Bandung: Alfabeta.

[4] Suyasa, P \& Fransisca. 2005. Perbandingan Perilaku Konsumtif Berdasarkan Metode Pembayaran. Phronesis, 7(2), 172-198.

[5] T Tambunan, R. 2001. Remaja dan Perilaku Konsumtif. Retrieved 23 July 2019, from http://www.e-psikologi.com. 